\title{
Neonatal Abstinence Syndrome and Medical Social Service Management
}

\author{
Ali Bulbul $^{1 \oplus}$, Evrim Yapici Celiker ${ }^{2 \oplus}$, Umran Calapcikay $^{3 \oplus}$, Sinan Uslu ${ }^{1 \oplus}$
}

\begin{abstract}
:
Neonatal abstinence syndrome and medical social service management

There is not enough data about the frequency of illegal drug use during pregnancy in developing countries and consequently the incidence of neonatal abstinence syndrome in newborn infants is unknown. In recent years, a significant increase in the number of cases reported as neonatal abstinence syndrome has been detected in the literature. Due to the social and religious culture of our society, health care practitioners do not receive sufficient and accurate information from patients and their relatives. Often, this situation is revealed by the awareness of the health care practitioner. In this review, the illegal substances frequently used in pregnancy, the findings and treatment of these substances in the newborn baby, the current legal situation related to the subject in our country and the procedures of social services related to the subject were discussed and the procedures to be followed in this case were evaluated.

Keywords: Abstinance, drug, newborn, opioid

ÖZET:

Neonatal yoksunluk sendromu ve tıbbi sosyal hizmet yönetimi

Gelişmekte olan ülkelerde gebelik süresince illegal ilaç kullanımı ve buna bağlı olarak yenidoğan bebeklerde neonatal yoksunluk sendromu görülme sıklığı ile ilgili yeterli veri bulunmamaktadır. Son yıllarda olgu sunumları olarak bildirilen yayınlarda önemli bir oranda artış saptanmıştır. Toplumumuzun sosyal ve inanç kültürü nedeniyle sağlık çalışanları hastadan ve hasta yakınlarından yeterli ve doğru bilgi alamamaktadır. Genellikle bu durum sağlık çalışanın farkındalığı ile ortaya konmaktadır. Konu ile ilgili derlememizde gebelikte sıklıkla kullanılan yasadışı maddeler, bu maddelerin yenidoğan bebekte saptanan bulguları ve tedavisi, ülkemizde konu ile ilgili mevcut hukuki durum ve sosyal hizmetlerin konu ile ilgili işleyiş prosedürü ele alınmış, bu durumda saptanan bebekler ile ilgili izlenmesi gereken işlemler değerlendirilmiştir.
\end{abstract}

Anahtar kelimeler: Yoksunluk, ilaç, yenidoğan, opioid

Ş.E.E.A.H. Tıp Bülteni 2017;51(4):266-77
${ }^{1}$ Health Sciences University, Sisli Hamidiye Etfal SUAM, Department of Neonatology,

Istanbul - Turkey

${ }^{2}$ Health Sciences University, Okmeydani SUAM, Department of Pediatrics, Istanbul - Turkey

${ }^{3}$ Sisli Hamidiye Etfal Training and Research

Hospital, Medical Social Services Unit,

Istanbul - Turkey

Address reprint requests to / Yazışma Adresi:

Ali Bulbul,

Health Sciences University, Sisli Hamidiye Etfal SUAM, Department of Neonatology,

Istanbul - Turkey

E-mail / E-posta:

drbulbul@yahoo.com

Date of receipt / Geliş tarihi:

August 15, 2017 / 15 Ağustos 2017

Date of acceptance / Kabul tarihi: September 11, 2017 / 11 Eylül 2017

\section{INTRODUCTION}

Our knowledge of illegal drug use during pregnancy is in particular of opioid use and most of the available information is obtained from the United States (USA) where opioids have been legally used extensively in the past. For the first time in 1827, morphine was marketed legally as a painkiller in the USA and then in 1898, diacetyl morphine (Heroin) was marketed as a reliable painkiller without side effects instead of morphine. Until morphine use was banned in 1914, three opioid epidemics has developed in America (1). In the following periods, the epidemic of heroin use occurred twice in the 1950s and 1960s. In the last decade, the frequency of opioid use during pregnancy has increased about 4 times. In the USA in 2000s, the rate of opioid use was 1.19 in 1000, compared to 5.63 in 2009. Similar to these rates in the same period, the incidence of abstinence syndrome in the neonatal intensive care unit (NICU) increased rapidly from 7 to 27 per 1000 infants (2). 
Substance use during pregnancy causes fetal death, intrauterine growth retardation (IUGR), placental insufficiency, postpartum hemorrhage, preeclampsia and early membrane rupture (3). In infants of mothers who use substance during pregnancy; neonatal abstinence syndrome (NAS), postpartum neurobehavioral disorders, congenital malformations, long-term growth and development retardation, maternal poor care, and exposure to infectious infections may be seen. Opioid substitution programs in pregnancy reduce these complications and it is reported that methadone or buprenorphine can be used for this purpose (3). Although buprenorphine is reported to be more effective in the management of the side effects of opioids, long-term side effects on pregnancy and infants are not fully known (3).

The main principles of treatment of the babies of substance-dependent mothers include; ensuring the growth and development of the baby, establishing postpartum mother-infant relationship, ensuring the comfort of the baby and treatment of convulsions.

Our knowledge of the side effects of legal or illegal drug use in pregnancy is often obtained from developed countries that have established a system of follow-up on the subject. As there are no adequate monitoring systems in emerging countries such as our country, detailed data on the frequency and consequences of maternal substance use in pregnancy can not be collected and adequate measures cannot be taken to correct the situation. In our country, there is no study reporting the prevalence of substance abstinence in pregnancy. There are reviews in our country that include case reports from different centers (4-8).

\section{Definitions of the Effects of Drugs or Substances Used in Pregnancy}

Use: Rare consuming of alcohol, medication or a substance without any side effects.

Abuse: The use of alcohol or medication is more common, but only the user experiences some side effects.

Physical dependence: The appearance of physical findings when the drug or alcohol used is discontinued or its dose is reduced, or the antagonist is administered.
Psychological dependence: The elimination of negative effects in the absence of the drug or substance or the need for a psychoactive drug for the drug's positive effects.

Addiction: It is a chronic disorder of the mind's behavioral functioning. Motivation includes memory and communication paths between the two. The person has to resort to pathological ways to get the substance to relieve himself/herself because of the communicational disorders. The person can not stay away from the substance, and loses the behavioral control.

\section{Medical History}

Individuals with potential risk factors for substance use should be questioned in terms of any use. Individuals with the following characteristics have a risk factor in terms of substance use.

1. Adolescent pregnancy, especially in the case of out-of-marriage and low educational levels

2. Those who doesn't have pregnancy follow ups

3. Those with poor work or school performance

4. People with sexually transmitted diseases

5. Those with problems at home or in case of not living with the child

6. Those with behavioral changes (sleep disorders, agitation, aggression, disorientation, depression, eating disorders and over weight loss).

7. Patients with problems in their medical history related to drug use (such as nasal mucosal atrophy, nasal septum perforation, persistent nasal discharge, cellulitis, osteomyelitis, tuberculosis, epiphora, conjunctivitis).

8. Mental retardation

9. Having a history of being questioned in the past due to crime associated with substance use

10. Anamnesis of substance use in spouse or family member of the individual

When substance use in pregnancy is determined, the frequency of substance use, the last time of use before delivery, the substances used, the route of use (oral, intranasal, subcutaneous or intravenous), whether the injector is used or not during use, whether the injector is shared with others should be questioned. 


\section{Diagnosis}

In developing countries, diagnosis usually comes with the doubt of the healthcare personnel. In conservative societies like our country, healthcare employees are usually not informed by the family members about the use of substance during pregnancy. Therefore, the diagnosis is often made with the knowledge and awareness of the healthcare professionals. Screening tests can be used to confirm the diagnosis.

\section{Screening Tests}

In developed countries, screening tests for alcohol use and drug use in all pregnancies are carried out, and it has been shown that the applied screening tests are cost-effective $(9,10)$. Below are the methods that can be used as screening tests.

Urine analysis: It is the easiest method to obtain and analyze. In suspected cases, it is often used to determine the substance that the baby is exposed to.

Meconium analysis: It may show the exposure after the $20^{\text {th }}$ week of gestation to substance. However, meconium should be taken before feeding with breast milk or formula. It is important to ensure rapid transfer to the analysis center.

Hair analysis: This technique has disadvantages such as the newborn has low hair volume and there's inability to take the hair sample due to some cultural differences. The limited availability of centers for drug analysis in hair also reduces the applicability of this method.

Analysis of umbilical cord tissue: Drug analysis can be performed from the umbilical cord tissue, but it is necessary to determine these centers in advance and determine, for example how to transport the specimen.

\section{Factors Affecting the Development of Clinical Course Related to Substance Use:}

Smoking: It has been reported that the prognosis of withdrawal syndrome is worse in infants of mothers who smoke in pregnancy. There is a study showing that the number of cigarettes the mother has consumed in the last 24 hours before delivery worsens the symptoms of withdrawal syndrome in the baby (11). Nevertheless, maternal smoking was not shown to cause a higher Neonatal Abstinence Syndrome (NAS) score (3).

SSRI (Selective Serotonin Reuptake Inhibitor) use It has been reported that the use of SSRI medications consumed as antidepressants in the last quarter of pregnancy causes constant crying, trembling, insomnia, fever, tremor, hypertonia, tachypnea, poor nutrition, sleep disorders and convulsions in the baby (12). It is not known exactly whether these findings are due to the effects of SSRI drugs or because of withdrawal. Studies of SSRI drug metabolites in umbilical cord blood of mothers using SSRIs have shown that the amount of reduction in drug metabolites is related to the development of symptoms and, is a side effect of the drug, being more than withdrawal (13). The use of SSRI during pregnancy did not have an effect on the initiation of pharmacological treatment in the baby while taking opioids, whereas the use of SSRI in the mother was detected to cause the NAS score and the total pharmacological drug used to be higher in the baby (3).

Prematurity: The prevalence of NAS in preterm infants is lower. This is explained by the less time of periofd for premature infants exposed to the substance, the lower number of receptors present as the brain development is at early stages, the lower rate of passage through placenta, and the lower rate of substance deposition due to the lower rate of fat tissue. However, other causes of low prevalence of NAS in premature babies are; the scoring system to be developed for term infants, the lack of a scoring system to evaluate premature infants, and the lack of maturity of the neuromotor system in preterm infants enough to indicate the withdrawal symptoms.

Pharmacogenomics - epigenetics: It is known that genetic differences in infants have a significant effect on withdrawal symptoms. In adult studies, effects of single nucleotide polymorphisms (SNPs) in especially the structure of mu-opioid receptor (OPRM1), multidrug resistance $(A B C B 1)$ and catechol-Omethyltransferase (COMT) genes on the addiction 
have been shown. In infants, the OPRM1 118A>G AG/GG, COMT 158A>G AG/GG genotypes are reported to stay for shorter periods in hospital and needed pharmacological support at lower doses (3). Babies with PNOC rs732636a allele and OPRK1 rs702764 C alleles have more pharmacological drug requirements and the requirement of use of dual drugs in these babies has been emphasized (3).

\section{SUBSTANCES USED DURING PREGNANCY}

\section{1- OPIOIDS}

Under the opioid title; morphine, codeine, heroin, methadone, and buprenorphine are present. Scientific data include extensive reports of morphine use. The findings of the baby due to opioid use in pregnancy are gathered under the name Neonatal Abstinence Syndrome (NAS).

\section{Neonatal Abstinence Syndrome}

In infants of mothers who use opioids in pregnancy, NAS can be seen with a rate of $60-80 \%$ (3). NAS causes clinical findings in three main systems. These are the central nervous system, autonomic nervous system and gastrointestinal system. NAS findings show individual characteristics and do not show clinical findings according to the substance dose. Individual's nephrepinephrine, dopamine and seratonin receptors are thought to play role in the physiopathology of this situation. Because of the clinical differences between individuals, a pharmacological drug requirement is not considered to diagnose NAS, and diagnosis is based on the presence of main findings of NAS.

\section{Pathophysiology of NAS}

Opioids affect via opioid receptors, G proteincoupled receptors ( $\mu, k$ and gamma receptors). Endogenous opioids are enkephalins, endorphins and endomorphins. Synthetic opioids include codeine, heroin, hydromorphone, fentanyl and methadone. They exist in many systems including mainly the central nervous system, peripheral nervous system and gastrointestinal system (14). The density and affinity of the $\mu$ receptors during the neonatal period is as good as that of adults (15). In the absence of opioids when chronically stimulated, the activity of opioid receptors is increased; cellular ionic imbalance due to increased adenylate cyclase activityoccurs. As a result, changes in neurotransmitter release occur and systemic effects show up (16). Opioids have low molecular weight and are soluble in water. Thus, they easily cross the placenta into the fetus. The placental disposition of opioids increases as gestational week progresses (17).

The region where the opioids are most effective is the locus coeruleus area in pons in the CNS. This area is the neuroendocrine core of the brain and is hypersensitive to opioids (18). The deprivation of opioids leads to excessive nephropefrin release and is responsible for the majority of the withdrawal symptoms (19). It casues decreased dopamine release in the ventral region of the midbrain (20), reduced serotonin release in the dorsal raphe nucleus (21) and increased acetylcholine release. Peripheral nervous system and autonomic nervous system are also affected.

\section{Clinical Findings of NAS}

After prenatal opioid exposure, withdrawal symptoms usually occur 48-72 hours after birth; the onset of symptoms sometimes occurs after 2 weeks and rarely after 4 weeks (1). The clinical findings depend on the drug type, dose, the half-life. Symptoms of heroin withdrawal begin at the first 24 hours, whereas findings of methadone or buprenorphine withdrawal begin at 24-72 hours (22). The withdrawal findings for all opioids may start at or after 5 days, so the minimum follow-up period for these babies should be 5 days (23). When opioidsareused with barbiturates orbenzodiazepines, the findings are delayed. However, if the time between the last opioid use and the delivery is longer than 1 week, the incidence of neonatal withdrawal findings decreases (24). The frequency of clinical manifestations, the time of onset of symptoms, and the duration of follow-up in substance use, of which are more frequently detected, during pregnancy are given in Table-1. 
Table-1: The time of onset of neonatal abstinence syndrome, frequency of occurrence and duration of findings.

\begin{tabular}{lccc}
\hline \multirow{2}{*}{ DRUGS } & \multicolumn{3}{c}{ Clinical findings } \\
\cline { 2 - 4 } & Time of Onset & Frequency (\%) & Duration of follow up (days) \\
\hline Opioids & & & \\
$\quad$ Heroin & $24-48$ & $40-80$ & $8-10$ \\
$\quad$ Methadone & $48-72$ & $13-94$ & $\geq 30$ \\
$\quad$ Buprenorphine & $36-60$ & $22-67$ & $\geq 28$ \\
Nonopioids & $24-48$ & $20-30$ & $2-6$ \\
$\quad$ SSRI & $24-48$ & $20-50$ & $2-6$ \\
$\quad$ Tricyclic antidepressant & 24 & $2-49$ & $7-10$ \\
$\quad$ Methamphetamine & &
\end{tabular}

In a NAS-suspected infant, the Modified Finnegan Score presented in Table 2 is used in both diagnosis and treatment follow-up. Clinical findings can be summarized as follows.

Central nervous system: Hyperirritability, excessive crying, high-pitched crying, insomnia, poor sleep, increased muscle tone, tremor, peeling of the skin due to excessive movement and rubbing, convulsions.

Autonomic nervous system: Hyperthermia, stretching, sweating, nasal congestion, sneezing.

Gastrointestinal system: Diarrhea, vomiting, absorption-swallowing dysfunction, desire of the baby for continuous breastfeeding, malnutrition.

Although there are different scoring systems for monitoring and treatment decision of NAS findings, the most commonly used and accepted scoring system today is the modified Finnegan scoring system. A score of $\leq 7$ in the first 48 hours of life is considered to indicate that the baby is not exposed to a substance or drug with a $95 \%$ probability (3). A score of 8 and above indicaties that the baby is exposed to opioid in pregnancy.

Factors affecting the occurence of symptoms of NAS

- Maternal exposure (substance used, accompanying drug use, duration and time of exposure, use of multiple substances, frequency and dose)

- Maternal factors (malnutrition, infection, accompanying psychiatric conditions)

- Plasental opioid metabolism

- Genetic properties

- Newborn charcteristics (Gestational week, drug metabolism, drugs)

- Environmental factors
Table-2: Modified Finnegan Score applied in diagnosis and defining treatment in neonatal abstinence withdrawal syndrome $(12,38)$.

\begin{tabular}{|c|c|}
\hline & Scoring \\
\hline \multicolumn{2}{|l|}{ Central Nervous System Findings } \\
\hline High-pitched crying & 2 \\
\hline Continuous high-pitched crying & 3 \\
\hline Sleep after feeding $<1$ saat & 3 \\
\hline Sleep after feeding $<2$ saat & 2 \\
\hline Sleep after feeding $<3$ saat & 1 \\
\hline Light tremor with stimulant & 1 \\
\hline Moderate-severe tremor with stimulant & 2 \\
\hline Light tremor without stimulant & 3 \\
\hline Moderate-severe tremor without stimulant & 4 \\
\hline Hyperactive Moro reflex & 2 \\
\hline Excessive Hyperactive Moro reflex & 3 \\
\hline Increased muscle tone & 2 \\
\hline Flaking skin & 1 \\
\hline Myoclonic beat & 3 \\
\hline Generalized seizures & 5 \\
\hline \multicolumn{2}{|l|}{ Metabolic, vasomotor, respiratory findings } \\
\hline Sweating & 1 \\
\hline Fever (37.5-38.3 C) & 1 \\
\hline Fever $(>38.4 \mathrm{C})$ & 2 \\
\hline Frequent yawning $(>3-4)$ & 1 \\
\hline Nasal congestion & 1 \\
\hline Sneezing $(>3-4)$ & 1 \\
\hline Nasal discharge & 2 \\
\hline Respiratory rate $>60 / d k$ & 1 \\
\hline Respiratory rate $>60 / \mathrm{dk}$ and retraction & 2 \\
\hline \multicolumn{2}{|l|}{ Gastrointestinal findings } \\
\hline Increased breastfeeding & 1 \\
\hline Malnutrition & 2 \\
\hline Regurgitation & 2 \\
\hline Projectile vomiting & 3 \\
\hline Fecal incontinence & 2 \\
\hline Watery stool & 3 \\
\hline
\end{tabular}

- Full-term pregnancy, appropriate maternal weight for the gestational week (25), multiple substance use (26), use with benzodiazepines (27), $\mu$-opioid receptor positivity (OPRM1 $118 \mathrm{AA}$ ) and catecholO-methyltransferase (COMT 158 AA) positivity 
(28) are the factors that definitely increase the severity of occurence of symptoms. Male gender (29), methadone use (30), smoking (31), and combined use with SSRIs (32) are the possible affecting factors.

In the case of opioid-induced withdrawal, the incidence of convulsions is $2-11 \%$ (33); but abnormal EEG findings are observed in more than $30 \%$ of newborns (34). The exact cause is unknown but it is believed to be due to the upregulation of sodium channels due to receptor instability (14). It responds well to opioid therapy. Convulsions have not been shown to adversely affect long-term neurodevelopment.

\section{Treatment of NAS}

\section{a. Non-pharmacological}

Environmental stimuli should be minimized and baby care should be provided in a quiet environment. Pacifiers and swaddle methods can be used to calm down the baby. Frequent feeding intervals (every 2-hours) should be attempted to reduce feeding intolerance. High-calorie nutrition should be provided to close the gap of energy deficit lost from excessive crying and mobility and to ensure weight gain. If the baby is suitable, she/he should stay in the same room with the mother, and if the mother is suitable, she should actively participate in the care of the baby. Participation of the mother in the baby care and being together in the same room reduces the need for pharmacological intervention.

\section{b. Pharmacological}

A specific drug and dose to be used in the treatment of NAS in newborn infants has not been defined. Many drugs are used in treatment, but it is known that the effects and long-term side effects show individual differences. Establishing a standard follow-up protocol for these babies in centers who follow up NAS, reduces the frequency of drug use by $50 \%$ (35). Successful treatment planning requires the establishment of a standard protocol that includes an approach to babieds with NAS and ongoing training of staff members is required.
The pharmacologic treatment is recommended to be initiated in the following situations:

1. When signs and symptoms cannot be controlled by nonpharmacologic therapy

2. Consecutive (with 4-hour intervals) Finnegan score to be $\geq 8$

3. When there are serious clinical findings such as seizures

4. It should be applied when severe vomiting / diarrhea leading to dehydration is seen.

\section{Medicines used in NAS Treatment}

\section{a. Morphine Treatment}

Morphine is the most commonly used first-line medication. AAP (American Academy of Pediatrics) recommends oral morphine as first-line treatment. The short half-life of morphine and its ease of titration is the reason why it is the first choice. Pharmacokinetic and pharmacodynamic effects of intravenous morphine vary from patient to patient (12). Various doses of morphine use are suggested in the literature. According to $A A P$, the use of morphine in the opioid withdrawal syndrome is as follows: the initial dose of $0.05 \mathrm{mg} / \mathrm{kg} /$ dose, every 3-4 hours, reducing the dose after 48 hours of stabilization (12). The daily dose is usually reduced by $10 \%$. Treatment can be discontinued when a total dose of $0.04 \mathrm{mg} / \mathrm{kg} /$ day is reached. After discontinuation of treatment, the patient should be followed for 24-48 hours in terms of withdrawal symptoms. There are different administration models in the literature. However, there are no studies comparing any two models. Also, there is no information about a standard application, regarding any dose increase or reduction in these applications.

\section{Weight-based dosing:}

It is the administration as $0.07 \mathrm{mg} / \mathrm{kg}$ every $4-6$ hours, when the score is $\geq 8$.

The daily dose is initiated at $0,4 \mathrm{mg} / \mathrm{kg}$.

When the sum of the three consecutive scales is $\geq 24$ or a single measure is $\geq 12$, the daily dose is increased by $20 \%$.

Phenobarbital $(20 \mathrm{mg} / \mathrm{kg}$ loading dose, a maintenance dose of $5 \mathrm{mg} / \mathrm{kg}$ ) should be added as a second medicament when the baby's daily requirement exceeds $1.25 \mathrm{mg} / \mathrm{kg}$. 
Table-3: Determination of dose of morphine according to Modified Finnegan Score monitoring in NAS treatment (3).

\begin{tabular}{|c|c|c|c|c|c|c|}
\hline & & \multicolumn{5}{|c|}{ Morphine dose (mg) } \\
\hline \multirow{7}{*}{$\begin{array}{l}\text { Treatment } \\
\text { according to } \\
\text { symptom }\end{array}$} & Score* & $\begin{array}{l}\text { Initial dose/ } \\
\text { Every } 4 \text { hours }\end{array}$ & $\begin{array}{c}\text { DOSAGE } \\
\text { INCREASE (Single } \\
\text { Score value) }\end{array}$ & \multirow{7}{*}{$\begin{array}{l}\text { If the daily dose } \\
\text { is } 1.6 \mathrm{mg} / \mathrm{day} \text {, } \\
\text { the second drug } \\
\text { phenobarbital is } \\
\text { added }\end{array}$} & \multirow{7}{*}{$\begin{array}{l}\text { If the patient is } \\
\text { stable } 48 \text {-hour } \\
\text { follow-up and the } \\
\text { general score is } \leq 8 \text {, } \\
\text { decrease the so by } \\
0.02 \mathrm{mg} / \mathrm{day}\end{array}$} & \multirow[t]{7}{*}{$\begin{array}{l}\text { The drug is } \\
\text { discontinued when } \\
\text { the dose is } 0.02 \mathrm{mg}\end{array}$} \\
\hline & $0-8$ & -- & No increase & & & \\
\hline & $9-12$ & $0.04 \mathrm{mg}$ & Increase by 0.02 & & & \\
\hline & $13-16$ & $0.08 \mathrm{mg}$ & Increase by 0.04 & & & \\
\hline & $17-20$ & $0.12 \mathrm{mg}$ & Increase by 0.06 & & & \\
\hline & $21-24$ & $0.16 \mathrm{mg}$ & & & & \\
\hline & $\geq 25$ & $0.20 \mathrm{mg}$ & & & & \\
\hline
\end{tabular}

*Modified Finnegan score value

After the baby is stabilized for 48 hours, the dose is reduced by $10 \%$ if the sum of the previous three score measures is $<18$ or is generally $<8$.

The drug is discontinued when the daily dose is $0.15 \mathrm{mg} / \mathrm{kg}$.

Rescue therapy: when uncontrollable symptoms develop between two doses, the amount of the previous dose is intercalated (3). The treatment according to the score value, independent of weight is given in Table-3 $(36,37)$.

b. Methadone: It doesn't Exist in our Country.

Compared with morphine in withdrawal syndrome in adults and children, it can be preferred in treatment because it reduces the length of hospital stay and duration of use. Wider range of dose (6-12 hours) is a significant advantage. Because its half-life is 25-32 hours, it provides a longer steady-state serum concentration compared to morphine (3). The pharmacokinetic effects of oral methadone in newborns vary from patient to patient and there is no extensive research on the subject. Notwithstanding the fact that the reported studies did not reveal any significant side effects, because the pharmacokinetics of methadone is not fully understood in the newborn period and its content of ethanol, its use is usually limited. There are different applications related to doses used, some of the units apply loading doses of $0.1 \mathrm{mg} / \mathrm{kg}$. As a recommendation, methadone is given as $0.1 \mathrm{mg} / \mathrm{kg} / \mathrm{dose}$ every 6 hours (39). The baby is followed up for 24-48 hours following stabilization and the dose is started to be reduced. If the baby is stable when the methadone dose falls to $0.01 \mathrm{mg} / \mathrm{kg}$ in 24 hours, the treatment is terminated. c. Buprenorphine: It doesn't Exist in our Country. It's a partial $\mu$-opioid agonist. It is administered sublingually. Its disadvantages is its ethanol content and its pharmacokinetics are unknown. However, it reduces the hospital stay by $30 \%$ compared to morphine (36). It reduces NAS frequency and severity compared to methadone (40). There are not enough pharmacokinetic studies on its use during the neonatal period. Studies are required regarding the effects and side effects of buprenorphine in the neonatal period.

\section{d. Tincture of Opium}

It contains 25 times higher active substance than morphine. It is not recommended to be used in the neonatal period, because it is very difficult to regulate the dosage and its overdose is very likely to happen.

\section{e. Naloxone (Opioid antidote)}

It is used alone or in combination with buprenorphine in treatment programs in the treatment of opioid addiction in adults and pregnant women. However, it may aggravate the withdrawal symptoms (convulsions) during the neonatal period. For this reason, its use in opioid withdrawal findings in the neonatal period is contraindicated.

\section{f. Phenobarbital}

It can be used in addition to morphine therapy or as the first step in initial therapy. It should be known that phenobarbital have no effect on gastrointestinal tract withdrawal symptoms (41). Phenobarbital is known to be able to control symptoms with a loading dose of $20 \mathrm{mg} / \mathrm{kg}$, followed by maintenance dose of 
$5 \mathrm{mg} / \mathrm{kg}$, and it may be effective especially in infants with a history of multiple drug use during pregnancy. The main problem with phenobarbital administration is that the drug causes long-term cognitive impairment and it's been demonstrated to pause the synapse development in animal experiments. Infants given phenobarbital with NAS showed no neurodevelopmental side effects at 36 months follow-up (42). For this reason, phenobarbital is still considered as an alternative drug that can be safely used in the treatment of NAS currently.

\section{g. Clonidine}

It's a selective alpha-2 sympathetic receptor agonist. It has been used in adults in findings of deprivation. Hypotension and arrhythmia may develop during its use. It is reported that it can be used as an additional second drug to morphine, but clonidine was detected to be not superior to phenobarbital. It has been reported that 3 babies were lost due to myocarditis and sudden infant death syndrome due to clonidine. In the meta-analysis of clonidine administration during neonatal period, clonidine alone had similar results with the use of morphine, therefore it is reported that the use of drugs other than opioid would be more appropriate (43). However, there is not yet sufficient knowledge on use of clonidine-only therapy (41).

\section{Breast Milk and Breastfeeding in NAS}

There is not a full consensus about the mother who uses opioid, breastfeeding her baby. The view of the mother about the situation has importance in this matter. Mother's breastfeeding should be supported in the following situations.

Conditions where the breastfeeding should be supported

a- The mother to accept the treatment during the prenatal follow-up and is decisive for continuing the treatment at postpartum period, the social service expert indicates that the mother is in the position to succeed

b- Absence of substance use during the last 90 days before birth

c- Absence of substance in maternal urine screening test at birth d- Having regular prenatal care

e- No contraindication for breastfeeding (such as HIV infection)

Situations where breastfeeding should be stopped

a- The absence of regular prenatal follow-up of the mother

b- Reuse of substance within 30 days before birth

c- The mother to be not willing to be treated for substance addiction and to be not in communication with social service workers

$\mathrm{d}$-Presence of substance in urine screening test at birth

e- Not to be approving the plan for treatment in the postpartum period

$\mathrm{f}$ - The presence of clinical findings of active substance use in the mother

\section{2-ALCOHOL}

Alcohol use during pregnancy and its effects on the baby differs from each other. A wide range of disorders such as fetal alcohol syndrome, partial fetal alcohol syndrome, alcohol-related neurodevelopmental disorders, alcohol-related congenital defects, and neurobehavioral disorders associated with alcohol exposure during pregnancy can be mentioned. The alcohol is teratogenic for the fetus and causes irreversible damage on the fetal central nervous system. The issue of alcohol use in pregnancy will not be addressed in this section, as its effects on the baby and the perinatal prevention strategies are extensive.

\section{3-COCAINE}

Cocaine passes quickly through the placenta and joins into the baby's bloodstream. It causes vasoconstriction in placenta and fetus. The side effects are determined by which period of pregnancy and how often it is taken. Preterm birth causes low birth weight and fetal malnutrition. Its teratogenic effect has not been proven. In infants exposed to cocaine during the intrauterine period, the symptoms of withdrawal syndrome are not fully developed and it causes neurodevelopmental disorders in infants (44). The clinical findings are seen especially on $2^{\text {nd }}-3^{\text {rd }}$ 
days after birth as irritability, hyperactivity, tremor, crying out loudly, and desire of the baby for continuous breastfeeding (45). Since the cocaine metabolites can be detected in the baby's urine within the next 7 days after birth, it is considered that the clinical findings are the effect of cocaine more than withdrawal. Cocaine causes hypertension in the mother like pre-eclampsia. Beta-blockers are not recommended as antihypertensives in cocaine-induced hypertension treatment, because they would cause coronary ischaemia due to alpha-adrenergic stimulation. Nonpharmacologic measures and symptomatic treatment are recommended for treatment.

\section{4-MARIJUANA - MARIHUANA (CANNABIS)}

It is encountered as the most frequently used illegal substance during pregnancy (46). While the frequency of use during pregnancy is $2-5 \%$, it was reported that $50 \%$ of the women who used marijuana before pregnancy continued use during pregnancy (46). Although marijuana use in pregnancy is not associated with significant side effects for both obstetric labor and the fetus, it is generally accepted that babies are at risk because of the high use of smoking and other illegal substances in women who use marijuana during pregnancy. Symptomatic treatment is recommended because it is not considered to cause withdrawal symptoms.

\section{5- AMPHETAMINE (ECSTASY-CRYSTAL- love pill)}

As a strong stimulator, its use in women of gestational age is common. It is neurotoxic on cells with dopamine receptors in the brain. It does not cause a structural anomaly in the fetus. However, amphetamine use in pregnancy has been reported to increase the preterm birth, fetal malnutrition, low birth weight and newborn deaths as 2 times (47). The development of amphetamine-dependent withdrawal syndrome is not fully understood. Although few studies have reported treatment of amphetamine withdrawal syndrome, these infants are thought to develop findings of withdrawal from other illegal drugs (47).

\section{6- BENZODIAZEPINES}

As a result of the use of benzodiazepine in pregnancy, the baby usually shows clinical signs 4-7 days after birth. In some cases, this can last up to 2-3 weeks (1). Clinical findings are similar to withdrawal syndrome but the course is better. In addition, 'floppy infant syndrome' (severe hypotonia) can be seen. There is no accepted practice for pharmacological agents or methods to be applied in the case of benzodiazepine withdrawal in newborns (3).

\section{EFFECTS OF HEALTH CARE PRACTITIONERS ON SUBSTANCE USE DURING PREGNANCY}

The health care practitioner must have knowledge of the obligation to notify the use of substances in pregnancy and the legal aspects of the subject. Whether laws permit the screening tests to be applied, whether the result of the positive screening tests should be reported or not, or whether the individual characteristics of the subject can be shared or not, should be determined within the framework of the law. The health care practitioner should provide patient management according to the laws in the region where she/he lives.

Syphilis, gonorrhea, chlamydia, hepatitis B and C, HIV and tuberculosis should be screened in cases where substance use is detected.

Many illegally used medicines pass to the baby through breast milk. AAP reports that mothers who continue to take amphetamines, cocaine or phencyclidine are not recommended to breastfeed their babies due to long-term neurobehavioural adverse effects, while maternal milk can be continued in cases where the mother can be treated and the substance use can be controlled (maternal methadone or buprenorphine intake) (48).

In cases where illegal substance use in pregnancy and neonatal abstinence syndrome are detected; a multidisciplinary approach should be demonstrated in the assessment of both the mother or the baby. The treatment group should include a gynecologist, a pediatrician, a psychiatrist, a social service practitioner, and a substance addiction professional. Legal counsel must be available when required. 


\section{DRUG ADDICT MOTHER AND NEONATAL ABSTINENCE SYNDROME MANAGEMENT BY SOCIAL SERVICES}

\section{MEDICAL SOCIAL SERVICE APPLICATIONS}

Definition of Social Services: Social service aims to improve the functioning of the communities in which people are involved, social relations and institutions that develop with relationships. The aim of social service; is to improve social life, to increase solidarity among people and to raise solidarity in society (49). In Social Services Law No. 2828; Social Services is defined as the whole systematic and programmed service that aims to help people and families to prevent and solve social problems and to improve and raise living standards by eliminating the financial, moral and social deprivations that arise from their own internal and environmental conditions or outside their control and meet their needs. Within this framework, it is defined as a profession and a discipline that provides services in the context of individual-focused, at micro, mezzo and macro levels, with professional cooperation and as a result of acquired knowledge, skills and values (50).

Medical Social Service: Hospital Medical Social Services Units perform their functions in the light of the Medical Social Service Implementation Directive and explain their objectives in the directive as follows; determining the procedures and principles regarding the planning, implementation, evaluation and supervision of medical social service in order to solve the psychosocial and socio-economic problems affecting the treatment process of the patients that take service from health care institutions in a timely manner, by using the methods and techniques of the social service profession and discipline, and to ensure that medical social service practices are carried out in an effective and accessible manner with an understanding based on human rights, equality and social justice (51).

Social Worker: The medical staff who have graduated from the four-year social services departments of the universities, who identify the psycho-social and socio-economic problems of the patients admitted to the hospital, and plan and implement social work interventions related to their problems (51).

The infant cases, which are clinically diagnosed by the clinicians with NAS and are consulted the Medical Social Services Unit, are handled within the scope of the neglected child, and the social worker prepares the necessary professional intervention plan. When the case is being assessed;

- Detailed information about the case will be obtained from the physicians and other health personnel who are in charge of the patient and who know/observe the mother,

- Mother and other family members are interviewed,

- Provincial Directorate of the Ministry of Family and Social Policies is required to make an on-site examination at the address of the family, by declaring with an official letter about the situation, which includes a suspected childneglect and a prompt feed-back about the situation is demanded,

- When the family and the baby with social problems are taken into consideration, an intervention plan is prepared and applied according to the baby's condition considering the high benefit of the baby. In this regard;

1 - In case of any suspect of the existence of elements that could put the baby's life at risk by the family; in the presence of law enforcement agencies, it is possible to place the child in an institution affiliated with the Provincial Directorate of the Ministry of Family and Social Policy (5395 In accordance with Article 5, Paragraph 1 (c) of the Child Protection Act).

2- In case of the baby to be abandoned by her/his mother; in the presence of law enforcement agencies, it is possible to place the child in an institution affiliated with the Provincial Directorate of the Ministry of Family and Social Policy (5395 In accordance with Article 5, Paragraph 1 (c) of the Child Protection Act).

3- In case of suspect of care of the baby by the family; A notification including a suspect of child neglect with an official letter to the Provincial 
Directorate of the Ministry of Family and Social Policy is sent, and on-site insepction at the eddress of the family is requested. As a result of the on-site inspection of social inspection reports prepared by the occupational staff in the field, in accordance of the information stated in 5395 Child Protection Act, Article 5, Paragraph 3 (as required by Article 5, Paragraph 1); about the baby, preventive and supportive measures, counseling measures for the baby to be primarily protected in his or her family environment, educational measures, caring masures, health care measures and sheltering measures appropriate for the baby can be applied.

4- The family with socio-economic deprivation can be provided Socio-Economic Support (SES, cash aid) for children and young people, in the scope of the Regulation on Social and Economic Support Services.

To solve the problems related with the baby's siblings and their parents during the social reviews and analysis conducted at the family address;

- Appropriate precautions may be taken in

\section{REFERENCES}

1. Jones HE, Fielder A. Neonatal abstinence syndrome: Historical perspective, current focus, future directions. Prev Med 2015; 80: 12-7. [CrossRef]

2. Tolia VN, Patrick SW, Bennett MM, Murthy K, Sousa J, Smith PB, et al. Increasing incidence of the neonatal abstinence syndrome in U.S. neonatal ICUs. N Engl J Med 2015; 372: 2118-26. [CrossRef]

3. Kraft WK, Stover MW, Davis JM. Neonatal abstinence syndrome: Pharmacologic strategies for the mother and infant. Semin Perinatol 2016; 40: 203-12. [CrossRef]

4. Koyuncuoglu $H$. The combination of tizanidine markedly improves the treatment with dextromethorphan of heroin addicted outpatients. Int I Clin Pharmacol Ther 1995; 33: 13-9.

5. Okan F, Bulbul A, Nuhoglu A. Gebelikte madde suistimali. Çocuk Dergisi 2007; 7: 76-80.

6. Can E, Bülbül A, Uslu S, Güran O, Nuhoğlu A. Neonatal yoksunluk sendromu. Ş.E.E.A.H. Tıp Bülteni 2010: 44; 124-7.

7. Kale-Çekinmez E, Mutlu B, Yapıcıoğlu H, Ozlü F, Asker H, Mert $K$, et al. Two newborns of heroin-addicted mothers suffering neonatal withdrawal syndrome. Turk J Pediatr 2012; 54: 421-4.

8. Özdemiroğlu N, Kara S, Kurt CC, Arıkan Fi, Dallar Bilge Y. Neonatal yoksunluk sendromu olan prematüre bebek. Ege Tıp Dergisi 2014; 53: 102-5.

9. Wong $S$, Ordean A, Kahan M; Maternal Fetal Medicine Committee.; Family Physicians Advisory Committee.; MedicoLegal Committee.; Society of Obstetricians and Gynaecologists of Canada. Substance use in pregnancy. J Obstet Gynaecol Can 2011; 33: 367-84. [CrossRef] accordance with the 5395 Child Protection Act Article 5, paragraph 5 for the identified cases in other siblings.

- SES may also be provided for the other siblings.

- Professional assistance (AMATEM support, psychiatric follow-up) may be provided to treat the mother who has substance use.

- Psycho-social support may be provided to parents and children.

In order to raise the babies in their own family environment, the family may be strengthened by socio-economic-psycho-social aids and measures applied to children. In addition to this, considering the high benefit of the child, in cases where parents are detected to not to be able to care for the child, or in cases where life-threatening risk is suspected, the baby is accepted in the scope of need for protection [Child with need for protection: physical, mental, moral, social and emotional development and personal development is under risk, or neglected or abused, or crime victim child (52)] and is taken under protection with urgent protection decision.

10. Goler NC, Armstrong MA, Osejo VM, Hung YY, Haimowitz M, Caughey $A B$. Early start: a cost-beneficial perinatal substance abuse program. Obstet Gynecol 2012; 119: 102-10. [CrossRef]

11. Kaltenbach K, Holbrook AM, Coyle MG, Heil SH, Salisbury AL, Stine $S M$, et al. Predicting treatment for neonatal abstinence syndrome in infants born to women maintained on opioid agonist medication. Addiction 2012; 107: 45-52. [CrossRef]

12. Hudak ML, Tan RC; COMMITTEE ON DRUGS.; COMMITTEE ON FETUS AND NEWBORN.; American Academy of Pediatrics. Neonatal drug withdrawal. Pediatrics 2012; 129: e540-60. [CrossRef]

13. Laine $K$, Heikkinen T, Ekblad U, Kero P. Effects of exposure to selective serotonin reuptake inhibitors during pregnancy on serotonergic symptoms in newborns and cord blood monoamine and prolactin concentrations. Arch Gen Psychiatry 2003; 60: 720-6. [CrossRef]

14. Feng Y, He X, Yang Y, Chao D, Lazarus LH, Xia Y. Currentresearch on opioid receptor function. Curr Drug Targets 2012; 13: 230-46. [CrossRef]

15. Barr GA, McPhie-Lalmansingh A, Perez J, Riley M. Changing mechanisms of opiate tolerance and withdrawal during early development: animal models of the human experience. ILAR J 2011; 52: 329-41. [CrossRef]

16. Rehni AK, Jaggi AS, Singh N. Opioid withdrawal syndrome: emerging concepts and novel therapeutic targets. CNS Neurol Disord Drug Targets 2013; 12: 112-25. [CrossRef]

17. Nanovskaya TN, Nekhayeva, Hankins GDV, Ahmed MS. Transfer of methadone across the dually perfused preterm human placental lobule. Am J ObstetGynecol 2008; 198: 126.e1-e4. [CrossRef] 
18. Scavone JL, Sterling RC, Van Bockstaele EJ. Cannabinoid and opioid interactions: implications for opiate dependence and withdrawal. Neuroscience 2013; 248: 637-54. [CrossRef]

19. Little PJ, Price RR, Hinton RK, Kuhn CM. Role of noradrenergic hyperactivity in neonatal opiate abstinence. Drug Alcohol Depend 1996; 41: 47-54. [CrossRef]

20. SpigaS, Puddu MC, Pisano M, Diana M. Morphine withdrawalinduced morphological changes in the nucleus accumbens. Eur J Neurosci 2005; 22: 2332-40. [CrossRef]

21. Lauden J, Kerby LG. Opiate exposure and withdrawal dynamically regulate $m R N A$ expression in the serotonergic dorsal raphe nucleus. Neuroscience 2013; 254: 160-72. [CrossRef]

22. Zelson C, Rubio E, Wasserman E. Neonatal narcotic addiction: 10 year observation. Pediatrics 1971; 48: 178-89.

23. Kandall SR, Gartner LM. Late presentation of drug withdrawal symptoms in newborns. Am J Dis Child 1974; 127: 58-61. [CrossRef]

24. Steg N. Narcotic withdrawal reactions in the newborn. AMA J Dis Child 1957; 94: 286-8. [CrossRef]

25. Liu AJW, Jones MP, Murray H, Cook CM, Nanan R. Perinatal risk factors for the neonatal abstinence syndrome in infants born to women on methadone maintenance therapy. Aust N Z J Obstet Gynaecol 2010; 50: 253-8. [CrossRef]

26. Johnson K, Greenough A, Gerada C. Maternal drug use and length of neonatal unit stay. Addiction 2003; 98: 785-9. [CrossRef]

27. Pritham UA, Paul JA, Hayes MJ. Opioid dependency in pregnancy and length of stay for neonatal abstinence syndrome. J Obstet Gynecol Neonatal Nurs 2102; 41: 180-90. [CrossRef]

28. Wachman EM, Hayes MJ, Brown MS, Paul J, Harvey-Wilkes $K$, Terrin N, et al. Association of OPRM1 and COMT singlenucleotide polymorphisms with hospital length of stay and treatment of neonatal abstinence syndrome. JAMA 2013; 309: 1821-7. [CrossRef]

29. O'Connor AB, O'Brien L, Alto WA. Are there gender related differences in neonatal abstinence syndrome following exposure to buprenorphine during pregnancy? J PerinatMed 2013; 41: 621-3. [CrossRef]

30. Bakstad B, Sarfi M, Welle-strand G, Ravndal E. Opioid maintenance treatment during pregnancy: occurrence and severity of neonatal abstinence syndrome. A national prospective study. Eur Addict Res 2009; 15: 128-34. [CrossRef]

31. Jones HE, Heil SH, Tuten M, Chisolm MS, Foster JM, O'Grady $K E$, et al. Cigarette smoking in opioid-dependent pregnant women: neonatal and maternal outcomes. Drug Alcohol Depend 2013; 131: 271-7. [CrossRef]

32. Wachman EM, Newby PK, Vreeland J, Byun J, Bonzagni A, Bauchner $H$, et al. The relationship between maternal opioid agonists and psychiatric medications on length of hospitalization for neonatal abstinence syndrome. J Addict Med 2011; 5: 293-9. [CrossRef]

33. Herzlinger RA, Kandall SR, VaughanHGJr. Neonatal seizures associated with narcotic withdrawal. J Pediatr 1977; 91: 638-41. [CrossRef]

34. van Baar AL, Fleury P, Soepatmi S, Ultee CA, Wesselman PJ. Neonatal behavior after drug dependent pregnancy. Arch Dis Child 1989; 64: 235-40. [CrossRef]
35. Hall ES, Wexelblatt SL, Crowley M, Grow JL, Jasin LR, Klebanoff $M A$, et al.; OCHNAS Consortium. A multicenter cohort study of treatments and hospital outcomes in neonatal abstinence syndrome. Pediatrics 2014; 134: e527-34. [CrossRef]

36. Jones HE, Kaltenbach K, Heil SH, Stine SM, Coyle MG, Arria AM, et al. Neonatal abstinence syndrome after methadone or buprenorphine exposure. N Engl J Med 2010; 363: 2320-31. [CrossRef]

37. Jansson LM, Velez M, Harrow C. The opioid-exposed newborn: assessment and pharmacologic management. J Opioid Manag 2009; 5: 47-55.

38. Finnegan LP. Neonatal abstinence syndrome: assessment and pharmacotherapy. In: Nelson $\mathrm{N}$, editor. Current therapy in neonatal-perinatal medicine. 2 ed. Ontario: BC Decker; 1990.

39. Wiles JR, Isemann B, Mizuno T, Tabangin ME, Ward LP, Akinbi $H$, et al. Pharmacokinetics of Oral Methadone in the Treatment of Neonatal Abstinence Syndrome: A Pilot Study. J Pediatr 2015; 167: 1214-20.e3. [CrossRef]

40. Jones HE, Heil SH, Baewert A, Arria AM, Kaltenbach K, Martin $P R$, et al. Buprenorphine treatment of opioid-dependent pregnant women: a comprehensive review. Addiction 2012; 107: 5-27. [CrossRef]

41. McQueen K, Murphy-Oikonen J. Neonatal Abstinence Syndrome. N Engl J Med 2016; 375: 2468-79. [CrossRef]

42. Shankaran S, Papile LA, Wright LL, Ehrenkranz RA, Mele L, Lemons JA, et al. Neurodevelopmental outcome of premature infants after antenatal phenobarbital exposure. Am J Obstet Gynecol 2002; 187: 171-7. [CrossRef]

43. Streetz VN, Gildon BL, Thompson DF. Role of Clonidine in Neonatal Abstinence Syndrome: A Systematic Review. Ann Pharmacother 2016; 50: 301-10. [CrossRef]

44. Salisbury AL, Lester BM, Seifer R, Lagasse L, Bauer CR, Shankaran $S$, et al. Prenatal cocaine use and maternal depression: effects on infant neurobehavior. Neurotoxicol Teratol 2007; 29: 331-40. [CrossRef]

45. Chiriboga CA, Brust JC, Bateman D, Hauser WA. Dose-response effect of fetal cocaine exposure on newborn neurologic function. Pediatrics 1999; 103: 79-85. [CrossRef]

46. Moore DG, Turner JD, Parrott AC, Goodwin JE, Fulton SE, Min $M O$, et al. During pregnancy, recreational drug-using women stop taking ecstasy (3,4-methylenedioxy-N-methylamphetamine) and reduce alcohol consumption, but Continue to smoke tobacco and cannabis: initial findings from the Development and Infancy Study. J Psychopharmacol 2010; 24: 1403-10. [CrossRef]

47. Gorman MC, Orme KS, Nguyen NT, Kent EJ 3rd, Caughey AB. Outcomes in pregnancies complicated by methamphetamine use. Am J Obstet Gynecol 2014; 211: 429.e1-7. [CrossRef]

48. Section on Breastfeeding. Breastfeeding and the use of human milk. Pediatrics 2012; 129: e827-41. [CrossRef]

49. Robert Adams, Lena Dominelli, Malcolm Payne. Social Work: Themes, Issues and Critical Debates. 3rd Edition. Palgrave, UK, 2009. p.33

50. Veli Duyan. Sosyal Hizmet Temelleri Yaklaşımları Müdahale ve Yöntemleri. Ankara, 2010. syf. 29-30.

51. Tıbbi Sosyal Hizmet Uygulama Yönergesi. https://www.tkhk.gov. tr/1758_tibbi-sosyal-hizmet.

52. 5395 Çocuk Koruma Kanunu Kabul Tarihi 3.7.2005. http://www. resmigazete.gov.tr/main.aspx?home=http://www.resmigazete. gov.tr/eskiler/2005/07/20050715.htm\&main=http://www. resmigazete.gov.tr/eskiler/2005/07/20050715.htm 